\title{
To Study the Effect of Seed Treatment and Foliar Nutrition on Growth and Yield of Field pea (Pisum sativum L.) under Utera System
}

\author{
Tarun*, D.K. Chandrakar and Krishna Kumar \\ Department of Agronomy, Indira Gandhi Krishi Vishwavidhyalaya, Raipur-492012, \\ Chhattisgarh, India \\ *Corresponding author
}

\begin{tabular}{l} 
Ke y w or d s \\
$\begin{array}{l}\text { Field pea (Pisum } \\
\text { sativum L.), Utera } \\
\text { or paira, Nutrition }\end{array}$ \\
\hline Article Info \\
\hline $\begin{array}{l}\text { Accepted: } \\
\text { 04 October } 2018 \\
\text { Available Online: } \\
\text { 10 November } 2018\end{array}$ \\
\hline
\end{tabular}

A B S T R A C T

A field experiment was conducted during rabi season of 2017-18 at Instructional cum Research Farm, Indira Gandhi Krishi Vishvavidhyalaya, Raipur, Chhattisgarh. Utera or paira cropping (relay cropping) is age old double cropping system under the rainfed conditions in which succeeding utera crop is directly broadcasted in the standing rice crop after the flowering stage (Sharma et al., 2004). Fieldpea are a valuable source of protein for both man and animals. The majority of pea proteins are storage proteins, or globulins, and the amino acid profile of these proteins determines their nutritional value. The experiment was laid out in Factorial Randomized Block Design having the combination of twelve treatments and three replications. The treatment consisted of two seed treatment and six foliar nutrients spray. Seed treatment, $\mathrm{S}_{2}$ : Seed treatment with Rhizobium + PSB + fungicide + Sodium molybdate @ $0.5 \mathrm{~g} \mathrm{~kg}^{-1}$ seed recorded higher growth character, yield attributes and seed yield than with $\mathrm{S}_{1}$ : Seed treatment with Rhizobium + PSB + fungicide under rainfed rice - utera condition. As regards to foliar nutrients $\mathrm{F}_{5}$ : $0.5 \% \mathrm{NPK}$ (19:19:19) spray at branching and 15 days after $1^{\text {st }}$ spray was found superior among other foliar nutrient sprays in respect of growth characters, yield attributes and yield under rain fed rice - utera system.

\section{Introduction}

Utera or paira cropping (relay cropping) is age old double cropping system under the rainfed conditions in which succeeding utera crop is directly broadcasted in the standing rice crop after the flowering stage (Sharma et al., 2004). It is prevalent in shallow rainfed lowland ecosystem of Eastern India. This system is important for resource poor farmers as it incurs no expenditure on land preparation and irrigation. Also, the system improves the land use efficiency of a vast tract of rice fallow, smoothers weed, adds organic matter and nitrogen, especially when pulse crop is grown. Thus, it entails resource conservation technologies like zero tillage, no irrigation, crop diversification with legume, and organic matter build-up. In recent years, popularity of field pea as utera crop is increased. Pea starch, like that of most other starchy pulses, contains an intermediate level of amylose, which is reflected in its unique functionality and its higher levels of enzyme-resistant starch and slowly digestible starch (as compared with 
cereal, root and tuber starches, most of which are lower in amylose). Protein content in peas (21.2-32.9\%), starch (36.9-49.0\%), Amylose (20.7-33.7\%), Total dietary fibre (14-26\%), Insoluble fibre (10-15\%), Soluble fibre (29\%), Soluble sugars (5.3-8.7\%), Total lipid (1.2-2.4\%) and Ash (2.3-3.4\%) (Wendy, 2012). Rhizobium inoculation is a significant technology for the manipulation of rhizobia for improving crop productivity and soil fertility. Rhizobium inoculation can lead to establishment of large rhizobia in the rhizosphere and improved nodulation and nitrogen fixation even under adverse soil conditions (Peoples et al., 1995). In fieldpea rhizobium inoculation is the process of applying rhizobium inoculants to the fieldpea seed before planting in order to increase the nitrogen fixation and nodulation of the fieldpea roots. Inoculating fieldpea provides adequate number of bacteria in the root zone, so that effective nodulation will take place. Fieldpea fixes and utilizes the atmospheric nitrogen in symbiotic association with Rhizobium leguminosarum bacteria. It also helps in enriching the $\mathrm{N}$-fertility by decaying of roots and nodules. Combined application of Rhizobium and phosphate solubilizing bacteria have synergistic action and stimulate their activity, however it is largely depended upon rhizospheric and climatic conditions.

\section{Materials and Methods}

A field experiment was conducted during rabi season of 2017-18 at Instructional cum Research Farm, Indira Gandhi Krishi Vishvavidhyalaya, Raipur, Chhattisgarh. To find out the effect of seed treatment and foliar nutrition on growth and yield of fieldpea under utera system. The soil of the experimental field was Vertisols with low, medium and high in $\mathrm{N}, \mathrm{P}$ and $\mathrm{K}$, respectively and neutral in reaction. The climate of the region is sub-humid to semi-arid. The experiment was laid out in Factorial
Randomized Block Design having the combination of twelve treatments and three replications. The treatment consisted of two seed treatment and six foliar nutrients spray.

The experiment was comprised of factor A. Seed treatments, $\mathrm{S}_{1}$ : Seed treatment with Rhizobium + PSB + fungicide and $\mathrm{S}_{2}$ : Seed treatment with Rhizobium + PSB + fungicide + Sodium molybdate@ $0.5 \mathrm{~g} \mathrm{~kg}^{-1}$ seed and factor B. Foliar nutrient spray, F1: Control (water spray), F2: 2\% Neem coated urea spray at branching, F3: 2\% Neem coated urea spray at branching and 15 days after $1^{\text {st }}$ spray, F4: 0.5\% NPK (19:19:19) spray at branching, F5: 0.5\% NPK (19:19:19) spray at branching \& 15 days after $1^{\text {st }}$ spray, F6: $2 \%$ DAP spray at branching and 15 days after $1^{\text {st }}$ spray. Fieldpea (Pisum sativum L.) variety Indira Matar-1 was sown $18^{\text {th }}$ October, 2017 with a seed rate of $100 \mathrm{~kg} \mathrm{ha}^{-1}$. The crop was harvested on $2^{\text {nd }}$ February 2018 (Fig. 1).

\section{Results and Discussion}

\section{Growth character}

Significantly taller plant was recorded under the $\mathrm{S}_{2}$ : Seed treatment with Rhizobium + PSB + fungicide + Sodium molybdate @ $0.5 \mathrm{~g} \mathrm{~kg}^{-1}$ seed as compared to $S_{1}$ : Seed treatment with Rhizobium + PSB + fungicide. During all the stages of observation except at 30 DAS whereas, it as found non-significant variation. Treatment $\mathrm{F}_{5}: 0.5 \%$ NPK $(19: 19: 19)$ spray at branching \& 15 days after $1^{\text {st }}$ spray gave significantly highest plant height of fieldpea and it was at par with $\mathrm{F}_{6}: 2 \%$ DAP spray at branching \& 15 days after $1^{\text {st }}$ spray except at 30 DAS. The maximum number of branches plant $^{-1}$ of fieldpea was recorded under the $S_{2}$ : Seed treatment with Rhizobium + PSB + fungicide + Sodium molybdate @ $0.5 \mathrm{~g} \mathrm{~kg}^{-1}$ seed then $\mathrm{S}_{1}$ : Seed treatment with Rhizobium + PSB + fungicide. Among foliar nutrient treatment $\mathrm{F}_{5}: 0.5 \%$ NPK $(19: 19: 19)$ spray at 
branching \& 15 days after $1^{\text {st }}$ spray, but it was at par with $\mathrm{F}_{6}: 2 \%$ DAP spray at branching \& 15 days after $1^{\text {st }}$ spray at 60 DAS. Karpagam et al., (2004) stated that foliar application of five sprays of NPK 19:19:19 along with the normal recommended dose recorded the highest plant height. Khalid et al., (2015) found that $\mathrm{N}_{3} \mathrm{P}_{3} \mathrm{~K}_{3} \quad \mathrm{x}$ foliar nutrition interaction, resulting in a positive increase in plant height. Krishnan et al., (2014) investigated that water soluble fertilizers (starter and booster) significantly increase the plant height $(100.40 \mathrm{~cm})$ and the number of branches (23.4). Mamathashree et al., (2016) reported that foliar spray of 19:19:19 @ 2\% had favorable effect on plant height $(185.9 \mathrm{~cm})$ (Table 1).

Fig.1 Experimental field

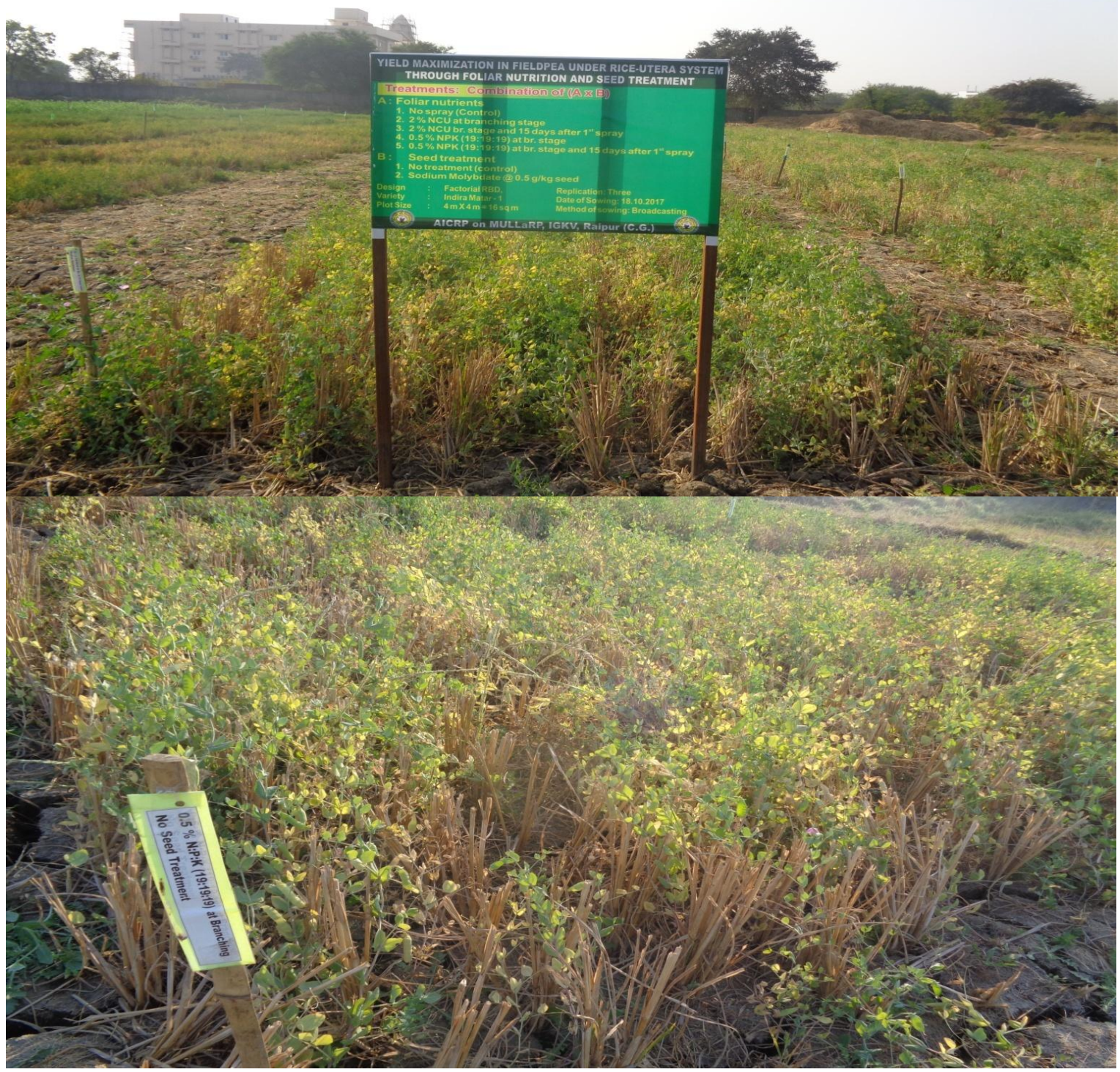


Table.1 Plant height of fieldpea at various duration as influenced by seed treatment and foliar nutrient spray

\begin{tabular}{|c|c|c|c|c|}
\hline \multirow{2}{*}{ Treatment } & \multicolumn{4}{|c|}{ Plant height (cm) } \\
\hline & 30 DAS & 60 DAS & 90 DAS & At harvest \\
\hline \multicolumn{5}{|l|}{ A. Seed treatments } \\
\hline $\mathrm{S}_{1}$ : Seed treatment with Rhizobium + PSB + fungicide & 16.8 & 40.5 & 51.6 & 59.6 \\
\hline $\begin{array}{l}\mathrm{S}_{2} \text { : Seed treatment with Rhizobium + PSB + fungicide + Sodium molybdate } \\
\text { @ } 0.5 \mathrm{~g} \mathrm{~kg}^{-1} \text { seed }\end{array}$ & 17.4 & 45.7 & 56.8 & 64.9 \\
\hline SEm \pm & 0.23 & 1.45 & 1.42 & 1.47 \\
\hline $\mathrm{CD}(\mathrm{P}=0.05)$ & NS & 4.26 & 4.16 & 4.30 \\
\hline \multicolumn{5}{|l|}{ B. Foliar nutrients spray } \\
\hline $\mathrm{F}_{1}:$ Control (Water spray) & 17.2 & 33.9 & 44.7 & 53.2 \\
\hline $\mathrm{F}_{2}: 2 \%$ Neem coated urea (NCU) spray at branching & 16.6 & 39.8 & 50.7 & 59.2 \\
\hline$F_{3}: 2 \%$ Neem coated urea (NCU) at branching and 15 days after $1^{\text {st }}$ spray & 17.1 & 44.0 & 55.3 & 62.2 \\
\hline$F_{4}: 0.5 \%$ NPK (19:19:19) spray at branching & 17.7 & 43.0 & 54.3 & 62.3 \\
\hline$F_{5}: 0.5 \%$ NPK (19:19:19) spray at branching $\& 15$ days after $1^{\text {st }}$ spray & 16.5 & 51.5 & 62.6 & 70.7 \\
\hline $\begin{array}{l}\text { F }_{6}: 2 \% \text { Diammonium phosphate (DAP) spray at branching \& } 15 \text { days after } \\
1^{\text {st }} \text { spray }\end{array}$ & 17.5 & 46.5 & 57.7 & 66.0 \\
\hline SEm \pm & 0.40 & 2.51 & 2.46 & 2.54 \\
\hline $\mathrm{CD}(\mathrm{P}=0.05)$ & NS & 7.37 & 7.21 & 7.44 \\
\hline Interaction (S x F) & NS & NS & NS & NS \\
\hline
\end{tabular}




\section{Yield attributes}

Numerically the maximum number of seeds pod $^{-1}$ was recorded in treatment $S_{2}$ : Seed treatment with Rhizobium + PSB + fungicide + Sodium molybdate @ $0.5 \mathrm{~g} \mathrm{~kg}^{-1}$ seed. In case of foliar nutrient treatment $\mathrm{F}_{5}: 0.5 \%$ NPK (19:19:19) spray at branching \& 15 days after $1^{\text {st }}$ spray was recorded maximum number of seeds pod $^{-1}$ and minimum was recorded under $\mathrm{F}_{1}$ : Control (Water spray). Treatment $\mathrm{S}_{2}$ : Seed treatment with Rhizobium + PSB + fungicide + Sodium molybdate @ $0.5 \mathrm{~g} \mathrm{~kg}^{-1}$ seed was found suitable in enhancing seed yield and Stover yield and thereby the harvest index. Under foliar nutrient treatment $\mathrm{F}_{5}: 0.5 \%$ NPK $(19: 19: 19)$ spray at branching and 15 days after $1^{\text {st }}$ spray was found suitable in enhancing seed yield and Stover yield and thereby the harvest index, however it was comparable with $\mathrm{F}_{6}$ : $2 \%$ DAP spray at branching and 15 days after $1^{\text {st }}$ spray and minimum was recorded under $\mathrm{F}_{1}$ : Control (water spray).

\section{References}

Karpagam, R., Kannan, M., Natarajan, S. and Srinivasan, K. 2004. Studies on the efficacy of foliar feeding of water soluble fertilizers on growth parameters and yield of brinjal (Solanum melongena L.) hybrid COBH-1. South Indian hort., 52(1-6):139-145.

Khalid, K.A. and Shedeed, M.R. 2015. Effect of NPK and foliar nutrition on growth, yield and chemical constituents in Nigella sativa L. J. Mater. Environ. Sci., 6(6): 1709-1714.

Krishnan, A., Indiresh K.M. and Anjanappa, M. 2014. Effect of water soluble fertilizers on growth and yield of tomato (Solanum lycopersicum L.). J.of Tropical Agric., 52(2): 154-157.

Mamathashree, C.M., Patil, M.B., Ashwini M. and Shilpa, H.D. 2016. Suitable water soluble fertilizers for increasing growth parameters of Pigeonpea. Res. Environ. Life Sci., 9(8): 931-932.

Peoples, M.B., Herridge, D.F. and Ladha, J.K. 1995. Biological nitrogen-fixation: an efficient source of nitrogen for sustainable agricultural production. Plant Soil. 174: 3-28.

Sharma R.S, Chandra D. and Saha S. 2004. Paira crop management including zero tillage for crop establishment. In: Recent advances in rice based farming systems. (Eds.), 17-19 November, 2004, Cuttack, Odisha, Central Rice Research Institute, 149-160.

\section{How to cite this article:}

Tarun, D.K. Chandrakar and Krishna Kumar. 2018. To Study the Effect of Seed Treatment and Foliar Nutrition on Growth and Yield of Field pea (Pisum sativum L.) under Utera System. Int.J.Curr.Microbiol.App.Sci. 7(11): 327-331. doi: https://doi.org/10.20546/ijcmas.2018.711.041 